\title{
POSTHEMIPLEGIC DYSTONIA: CLINICAL AND RADIOLOGICAL DATA OF 12 PATIENTS
}

\author{
Gülçin BENBİR ŞENEL, Sibel ÖZEKMEKÇİ, Güneş KIZILTAN, Özdem ERTÜRK, Hülya APAYDIN, \\ Sibel ERTAN, Birsen İNCE, Melda BOZLUOLCAY
}

İstanbul University Cerrahpasa Faculty of Medicine, Department Of Neurology, İSTANBUL

\begin{abstract}
Secondary dystonias due to ischemic and/or hemorrhagic lesions of the basal ganglia and thalamus are rare. Among 2369 patients with stroke, only 12 patients $(0.5 \%)$ developed posthemiplegic dystonia, which constituted $4.9 \%$ of 506 patients with dystonia. Posthemiplegic dystonia appeared as slow, twisting clonic spasms (mobile dystonia) in eight patients who had the distal parts of their extremities affected. On the other hand, in case of an arm or leg involved as a whole, posthemiplegic dystonia appeared as prolonged abnormal postures (fixed dystonia), as observed in our four patients. The latency till the appearance of dystonia following stroke was significantly shorter in mobile dystonia ( 9 months versus 61.5 months, $\mathrm{p}=0.05$ ). The fixed dystonia resulted from thalamic involvement in all four cases. On the other hand, mobile dystonia developed in three patients with thalamic involvement, but in all five patients with infarctions in putamen, caudate and lentiform nuclei. The rather low number of cases with basal ganglia/capsular lesions resulting in hemiplegia and leading to subsequent dystonia may be due to selective lesioning and blockade of selective neurotransmitter systems. Key Words: Posthemiplegic dystonia, mobile dystonia, fixed dystonia, thalamic lesions, putaminal lesions.
\end{abstract}

\section{POSTHEMIPLEJIKK DİSTONI: 12 HASTANIN KLINIKK VE RADYOLOJÍK VERILERİ}

\section{ÖZET}

Bazal gangliyonların ve talamusun iskemik ve/veya hemorajik lezyonlarına bağlı gelișen sekonder distoni nadir olarak görülmektedir. İnme birimizde takip edilen 2369 inme hastası arasında sadece 12 hastada $(\% 0,5)$ posthemiplejik distoni gelișmiştir; diğer yandan bu hastalar Hareket Bozukluğu birimimizde takip edilen 506 distoni hastasının \%4,9'unu oluşturmaktadır. Posthemiplejik distoni 8 hastada plejik uzuvların distal bölgelerini etkileyen, yavaş, burkulan klonik spazm (mobil distoni) şeklinde izlendi. Diğer yandan 4 hastamızda olduğu üzere, eğer bir kol ya da bacak bütün halinde plejiden etkilendi ise, posthemiplejik distoni uzun süreli, anormal postür (sabit distoni) şeklinde idi. İnme geçirilmesi ile distoni ortaya çıkması arasında geçen süre mobil distoni hastalarında anlamlı olarak daha kısaydı (9 aya karşın 61,5 ay, $\mathrm{p}=0,05$ ). Sabit distoni tüm 4 hastada talamik etkilenme sonucu ortaya çlkmıștı. Mobil distoni ise, 3 hastada talamik, 5 hastada ise putamen, kaudat ve lentiform çekirdeğin etkilenmesi sonucu ortaya çıkmıştı. Patofizyolojisinde, oldukça nadir olarak görülmesi nedeniyle, selektif bir lezyona bağlı olarak nörotransmiter sistemlerin de selektif olarak etkilenmesi düşünülmektedir.

Anahtar Sözcükler: Posthemiplejik distoni, mobil distoni, sabit distoni, talamik lezyonlar, putaminal lezyonlar.

\section{INTRODUCTION}

Posthemiplegic focal limb or hemidystonias are rare movement disorders attributed to contralateral lesions mostly in basal ganglia and thalamus, with relative sparing of the corticospinal tracts considered to be essential $(1,2)$. Although its pathogenesis is not clear, slowly evolving aberrant central nervous system sprouting subsequent to a nonprogressive cerebral insult has been postulated in the development and the persistence of the dystonic movements (3).

It seems that it is difficult to make a definitive conclusion about clinic-radiological correlation in dystonia. There are contradictory results even in more detailed radiological studies with volumetric

\footnotetext{
Corresponding author: Gülçin Benbir Şenel, MD. İstanbul University Cerrahpaşa Faculty of Medicine, Department of Neurology, İstanbul, Turkey. Telephone: +902124143000 E-mail: drgulcinbenbir@yahoo.com Received: $26.09 .2014 \quad$ Accepted: 08.01.2015

This article should be cited as following: Benbir Șenel G, Özekmekçi S, Kızıltan G, Ertürk Ö, Apaydın H, Ertan S, İnce B, Bozluolcay M. Posthemiplegic Dystonia: Clinical and Radiological Data of 12 Patients. Turkish Journal of Cerebrovascular Diseases 2015; 21 (2): 99-102 doi:10.5505/tbdhd.2015.33043.
} 
investigations. Lehericy et al. (4) have concluded that thalamic lesions result in myoclonic dystonia with predominating myoclonus and "thalamic" hand associating dystonic posture and slow, pseudo-athetoid movements in the lesion of ventral intermediate and ventral caudal nuclei of the thalamus; while postural and action tremor could also result from lesions in ventral intermediate nucleus of thalamus with abnormal functioning of the cerebello-thalamic pathways. Lee et al. showed that sixteen patients with dystonia were presented with lesions of different etiologies localized more posterior or medial to the ventrolateral and ventroanterior thalamic nuclei receiving pallidothalamic and nigro-thalamic afferents (5). Here we aimed to present our patients with posthemiplegic dystonia, and discuss the anatomoclinical correlation based on the clinical phenomenology.

\section{MATERIAL AND METHODS}

In this study, all patients followed-up in our Neurology Department, Movement Disorders and Stroke outpatient clinics for the last 15 years were retrospectively reviewed. All patients with stroke were documented by a cranial neuroimaging (computed tomography, CT) and/or magnetic resonance imaging (MRI). The diagnosis of posthemiplegic dystonia was made by the neurologists (S.O., G.K., H.A., S.E.) specialized in Movement Disorders. Patients with a history of exposure to drugs or any other agents that might have caused dystonia or those with a positive family history were excluded. The clinical data of the patients were recorded from the database of the clinics and collected in SPSS version 11.5 format for descriptive and frequency analysis.

\section{RESULTS}

Out of 2369 patients with ischemic or hemorrhagic stroke being followed-up in Stroke clinics, only 12 patients $(0.5 \%)$ developed dystonia and referred to movement disorders outpatient clinics. At the same period, a total of 506 patients were followed-up in movement disorders clinics with the diagnosis of dystonia. Of these, 263 patients had primary dystonia, while 243 patients had secondary dystonia, and 12 patients with dystonia following a cerebrovascular event constituted $4.9 \%$ of them.

The mean age of 12 patients $(9$ men and 3 women) was $45.5+18.8$ years, ranging between 8 and 70 years. Six patients had right-sided and six patients had left-sided hemiparesis. Hemihypoesthesia was accompanying the motor deficit in five patients (number 5, 6, 7, 10, and 12 in Table 1). Hemidystonia was present in 7 patients, while only the upper extremity was involved in 5 patients. The development of dystonia was observed 3 weeks to 12 years after stroke (with a mean of 23 months and a median of 5 months). The neurological examinations in patients revealed that the development of dystonia was always observed after complete or partial recovery (only in patient 2) from motor deficit. In cases where posthemiplegic dystonia affected distal parts of the extremities, the dystonic movements appeared as slow, twisting and sustained clonic spasms (mobile dystonia), that was observed in eight patients (Table 1). On the other hand, in case of an arm or leg involved as a whole, the dystonic movements appeared as prolonged abnormal fixed postures (fixed dystonia), that was seen in four cases (Table 1). Patients with mobile dystonia were much older than those having fixed type of dystonia (51.0 years versus 34.5 years, $\mathrm{p}=0.154$ ), though this difference did not reach statistically significant level. The gender of the patients was similar in two groups with different types of dystonia $(\mathrm{p}=0.236)$. However time to dystonia was significantly shorter in patients with mobile dystonia with a mean of 9 months, whereas the mean latency for the development of fixed dystonia was 61.5 months $(\mathrm{p}=0.05)$.

Cranial CT showed thalamic hemorrhage in 4 patients. Cranial MRI showed ischemic infarction in 8 patients, 4 having putaminal infarction, 3 with thalamic infarction, and one patient having infarction in caudate and lentiform nucleus. The localization of the brain insult revealed that fixed type of dystonia was resulted from thalamic involvement in all four cases $(2$ infarctions and 2 hemorrhages). On the other hand, other three patients with thalamic involvement (2 hemorrhages and 1 infarction) showed mobile type of dystonia. All 4 patients with putaminal infarction and one patient with infarction in caudate nucleus and lentiform nucleus developed mobile dystonia (see Table 1). Additional cranial MRI lesions were present in three patients (numbers 2, 7 and 11), who had infarctions in temporal and parietal lobes; and another patient (number 6) also had cerebellar infarction ipsilateral to thalamic infarction. 
Table 1. The clinical features of 12 patients with posthemiplegic dystonia.

\begin{tabular}{lccccccc}
\hline & Sex & $\begin{array}{c}\text { Age } \\
\text { (years) }\end{array}$ & Involved limb & Side & Latency & Type & Site of lesion \\
\hline $\mathbf{1}$ & Female & 8 & Hemidystonia & Right & 3 years & Fixed & Thalamic infarction \\
$\mathbf{2}$ & Male & 21 & Hemidystonia & Right & 3 weeks & Mobile & Putaminal infarction \\
$\mathbf{3}$ & Male & 25 & Upper extremity & Left & 2.5 years & Fixed & Thalamic infarction \\
$\mathbf{4}$ & Male & 41 & Upper extremity & Left & 3 months & Mobile & Putaminal infarction \\
$\mathbf{5}$ & Male & 46 & Hemidystonia & Left & 2.5 years & Mobile & Infarction in putamen, globus \\
& & & & & & pallidus, and caudate \\
$\mathbf{6}$ & Male & 47 & Upper extremity & Right & 5 months & Mobile & Thalamic infarction \\
$\mathbf{7}$ & Male & 51 & Hemidystonia & Right & 12 years & Fixed & Thalamic hemorrhage \\
$\mathbf{8}$ & Female & 54 & Upper extremity & Right & 4.5 months & Fixed & Thalamic hemorrhage \\
$\mathbf{9}$ & Male & 55 & Hemidystonia & Left & 4 months & Mobile & Thalamic hemorrhage \\
$\mathbf{1 0}$ & Male & 63 & Hemidystonia & Left & 2 months & Mobile & Putaminal infarction \\
$\mathbf{1 1}$ & Male & 65 & Hemidystonia & Right & 2 years & Mobile & Thalamic hemorrhage \\
$\mathbf{1 2}$ & Female & 70 & Upper extremity & Left & 3 months & Mobile & Putaminal infarction \\
\hline
\end{tabular}

\section{DISCUSSION}

We observed that all patients with posthemiplegic dystonia had brain lesions in thalamus and/or putamen, with one patient having a more extensive infarction involving putamen, globus pallidus and caudate. It was defined that acquired dystonia is a syndrome of thalamofrontal disinhibition due to structural disruption of inhibitory control of basal ganglia resulting in release of premotor cortical activity from thalamic influences $(6,7)$. Damage to the neuronal circuits connecting caudate, putamen, globus pallidus and thalamus was suspected for the development of dystonia following stroke (1). Furthermore, it was shown that patients with thalamic lesions had dystonia restricted to the distal extremities, and more predominantly on upper extremities $(5,8)$. This predominance of dystonia of the upper limb have been suggested to result from a preferential destruction of neurons involved in the control of upper arm movements according to the somatotopic organization of thalamus as evidenced in the ventral lateral nucleus and/or to a predominance of the topographic representation of the arm area in the ventral intermediate nucleus (8-10). In our study, we did not observe such a differentiation, thalamic or putaminal insults could both result in hemidystonia or focal upper extremity dystonia. However, a more specific definition of lesions in terms of subnuclear involvement of thalamus could differentiate the clinical presentation.
The development of dystonia was observed after a mean of 23 months following stroke with and a median of 5 months in our patients. The latency between the acute stroke and the onset of abnormal movement was reported to vary from less than a day to several years after the stroke (11). This latency was related in part to the type of movement disorder, with chorea developing the earliest and parkinsonism the latest. The mean latency from onset of hemiparesis to onset of hemidystonia was reported as about 15 years, however a very large range was also reported to vary from 2 weeks to 46 years. Although the pathophysiology of this phenomenon was poorly understood, it was speculated to be related to age at the time of injury and delayed-onset progression following stroke (11).

The phenomenological differences of dystonic spasms based on the affected parts of the limbs were also prominent. Especially in case of the involvement of hands or distal extremities, posthemiplegic dystonia was reported to present with mobile athetoid twisting movements (mobile dystonia), while dystonia affecting more proximal parts of extremities showed clinically fixed, immobile tonic spasms (fixed dystonia), which was in accordance with previously reported cases $(6,8)$. In our cases, two out of four patients with fixed dystonia had hemidystonia; however, the other two patients had dystonia only on their upper extremities. Moreover, it was suggested that fixed 
dystonic spasms were associated with lesions in the striatopallidal complex, while myoclonic dystonia was associated with lesions in the thalamus (8). It was recently reported that myoclonic dystonias with predominating myoclonus and slow, pseudo-athetoid movements were related to lesions in the ventral intermediate and ventral caudal nuclei of the thalamus $(4,12)$.

Although it is difficult to make a generalization from the limited number of patients, fixed type of dystonia was always resulted from thalamic involvement in our series, while other three patients with thalamic involvement showed mobile type of dystonia. On the other hand, putaminal involvement did always result in mobile dystonia, as observed in all four patients, and together with the patient with infarction in caudate nucleus and lentiform nucleus, as well. Similar to our observations, in two case reports, one patient with infarction in posterolateral thalamus, and two patients with thalamic hemorrhage had fixed type of dystonia $(13,14)$.

The rather low number of cases with basal ganglia/capsular lesions resulting in hemiplegia and leading to subsequent dystonia is also unexpected. The animal literature suggested that the gross lesions of the thalamus or lentiform nucleus did not cause dystonia, but a more selective blockade of neurotransmitter systems such as GABAergic transmission was needed (15). It could be argued that unless selective lesioning occurred or subsequent nerve spouting selectively innervated particular receptor types, the patient was spared from developing involuntary movements (16).

\section{REFERENCES}

1. Pettigrew LC, Jankovic J. Hemidystonia: a report of 22 patients and a review of the literature. J Neurol Neurosurg Psychiatry 1985;48:650-657.

2. Dooling EC, Adams RD. The pathological anatomy of posthemiplegic athetosis. Brain 1975;98:29-48.

3. Burke RE, Fahn S, Gold AP. Delayed-onset dystonia in patients with "static" encephalopathy. J Neurol Neurosurg Psychiatry 1980;43:789-797.

4. Lehericy S, Grand S, Pollak P, et al. Clinical characteristics and topography of lesions in movement disorders due to thalamic lesions. Neurology 2001;25:1055-1066.

5. Lee MS, Marsden CD. Movement disorders following lesions of the thalamus or subthalamic region. Mov Disord 1994;9:493-507.

6. Marsden CD, Obeso JA, Zarranz JJ, et al. The anatomical basis of symptomatic hemidystonia. Brain 1985;108:463-483.

7. Ceballos-Baumann AO, Passingham RE, Marsden CD, et al. Motor reorganization in acquired hemidystonia. Ann Neurol 1995;37:746-757.

8. Lehérichy S, Vidailhet $M$, Dormont $D$, et al. Striatopallidal and thalamic dystonia: a magnetic resonance imaging anatomoclinical study. Arch Neurol 1996;53:241-250.

9. Strick PL. Anatomical analysis of ventrolateral thalamic input to primate motor cortex. J Neurophysiol 1976;39:1020-1031.

10. Ohye C, Shibazaki T, Hirai T, et al. Further physiological observations on the ventralis intermedius neurons in the human thalamus. J Neurophysiol 1989;61:488-500.

11. Mehanna R, Jankovic J. Movement disorders in cerebrovascular disease. Lancet Neurol 2013;12:597-608.

12. Kim JS. Delayed onset mixed involuntary movements after thalamic stroke. Brain 2001;124:299-309.

13. Motoi $Y$, Hattori $Y$, Miwa $H$, et al. A case of post hemiplegic painful dystonia following thalamic infarction with good response to botulinus toxin. Rinsho Shinkigaku 1997;37:881-886.

14. Hamasaki T, Yamada K, Kuratsu J. Hemidystonia secondary to thalamic hemorrhage treated with GPi stimulation. Mov Disord 2008;23:1762-1766.

15. Baunez C, Robbins TW. Effects of transient inactivation of the subthalamic nucleus by local muscimol and APV infusions on performance on the five-choice serial reaction time task in rats. Psychopharmacol 1998;141:57-65.

16. Moy SS, Criswell HE, Breese GR. Differential effects of bilateral dopamine depletion in neonatal and adult rats. Neurosci Behav Rev 1997;21:425-435. 